\title{
The Amazon Rural Economy and the Social Way Cooperative
}

\author{
Celso Augusto Tôrres do Nascimento \\ Federal University of Amazonas (Brazil)/ Université Lyon 2 (France) \\ Email: celsotor@gmail.com \\ Iraildes Caldas Torres \\ Federal University of Amazonas (Brazil)/Université Lyon 2 (France) \\ Email: Iraildes.caldas@gmail.com
}

\section{Diogo Gonzaga Torres Neto}

Federal University of Rondônia (Brazil)

Email: diogo@unirbr

\section{Doi:10.5901/mjss.2014.v5n14p52}

\section{Abstract}

This study is an analysis of the theme of Brazilian Social Economy in the field of sociology of work. It presents the cooperativism like a solidarity model of social economy with emphasis to the work's cooperatives. Discusses the ontology of the work as a source of social being in which the worker of today that creates and recreates them as construct in the context of survival strategy. It is a more extensive research carried out at the Federal University of Amazonas and presents a lot of results. The search's field is was conducted in the Village called Nossa Senhora de Aparecida, localized in district of Coari, localized in Amazon State-Brazil, with workers of a rural cooperative that produces food to be purchased by public authorities of the District. Among the findings it is clear that the rural workers of the Amazon are capable of remake their way survival through the solidarity economy, even if under the nexus of capitalists relations. It Can say, finally, that the Social Economy presents itself as an economic activity promising and capable of responding to social development and environmentally sustainable.

Keywords: Social Economy, Rural Workers, Amazon.

\section{Introduction}

The organizational way that people be together to insert in the market economy, by collective methodology, is today a intelligent way to survive. The articulation of social elements and local economy with the new methodologies and Technological innovation was created by brazilian Universities, can shares a lot of resources and experiences to achieve greats results more than individual results from the all parts, or about the collective, in the hypothesis which that aren't articulates.

This new economic phase, hardly, an isolate effort from the company or corporation shall achieve to meet all the necessaries competences to face with success against the treats of market. Is possible which the cooperativism has a collectively style of the solidarity way of to share out profits, to be a economic survival strategy of some Amazon rural worker into development regional.

We are making references to the front of collective works express in the popular cooperatives like a Local Arrangements of Production - APL, which according Gohn (1997, p. 12), are "collectives actions to search solution for the specific problems, ground worked into community work.".

The flexibilization in the worker rights generate a labour with down salary with down social beneficial, are producing a deep impact inside social politicise, forced by reducing incentives financial of jobs for State Administration. According Giddens (1991), this dysfunction is the consequence of modernity qualifications which bring a excellence management with the chaos, this is building that the under development be an another face of development.

The no regular Jobs daily grow up and this activity there are a lot of workers employment or they working in the a lot of under work or harmful occupation, i.e., that job without works rights and that are far from focus the syndicate of 
professional class.

The principal hypothesis that appear because to resolve a employment problem is necessary to generate a forest people that live riverside a real opportunity to insert into economy by themselves.

\section{The Brazilian Society and the Cooperativism}

The Brazilian society is experiencing a moment promising a construction of new work culture that has on cooperation and solidarity the status of its development. This is the modality of work known as Social Economy that is introduced in Brazil, from the second half of the 1990s, in response to the large employment crisis afflicting the mass of workers in the country. At that time the sociologist Herbert de Souza, the Betinho, together with Jair Meneguelli, then president of the Single Central of Workers- CUT, in a meeting with the researchers from COPPE- Coordination of graduate Programs in Engineering of the Federal University of Rio de Janeiro, instigate the public university to contribute with the workers to cope with the crisis. It was born, thus, the UNITRABALHO-Foundation of Inter-University Research on the Work.

Founded in 1995, the Unitrabalho quickly grow and took breath within universities forming local cores that's strengthen and streamline this network of study and militancy in the thematic work in each federated State. In 1997, the research group of Unitrabalho coordinated by professor Paul Singer (USP) on the theme of solidarity economy, held a national event in which attended,

Leaders of Anteag, the ITCP/UFRJ, MST, FASE and some other promoters or associations of solidarity economy. This meeting was attended by colleagues Unitrabalho throughout the country and it was enlightening to hear the reports on cooperatives of new type that were being formed in many States. Beside the ITCP/UFRJ and Anteag, also the MST was creating cooperative production and marketing in agrarian reform settlements (SINGER, 2000, p.125 -126).

The cooperativism is kid of model of economic integration that puts man on the centrality of the productive process, whose character creator and nourisher of hominização assumes the perspective of human construct. The work has always existed in the history of humanity. It is through him that men and women are held as historical beings and social to assuage. It is from the capitalist industrialism that occurs the expropriation of the worker both of their means of production that allow them to provide their needs materials, as in his humanity. In Economic and Philosophical Manuscripts of 1844, Karl Marx (2004, p. 81) says that,

The exteriorization of the worker in your product has the meaning not only that their work becomes an object, an existence outside, but, as well, in addition, that becomes an existence that exists outside him, regardless him and strange to him, becoming a standalone power before him, that the life which he has given to the object if it faces hostile and strange.

This work instinctively felt something confined to the process of alienation, under the nexuses of capitalism, removes the mediating function and historic of human work. The human work is matched to the production of goods, as this route predominates the isolated individual, moved from its condition of collective worker, i.e. is a loved subordinated to the market and the economic determinations. There seems to be a so-called conceptual naturalization of capitalist relations of production. This is not the perspective of the economy of solidarity which is a modality of work that goes into the deep of capitalism, in its relations to title and exploitation of the work.

In addition to the economic aspects and the activity profitable in itself, the work is the source of social being. As Ranieri (2004, p. 14) "the work is, and will always be, an element whose mediating role is non-eliminated of society and, therefore, of human sociality". The ontology of the work is much more significant and symbolically expressive to the speech of the centrality of work. We are referring to the directions of the work activity as social history of humanization, in whose process occurs the objectification and exteriorization of the man, not as an individual alienated work, but how to be generic cognitive, which has vital activity aware that distinguishes it from animal activity. "Precisely, and for that reason alone, it's a generic". It is only one be aware, that is, his own life is object, precisely because it's a generic. This is because its activity is free activity (MARX, 2004, p. 84).1

The Social Economy was based on this perspective of free activity in so far as it is conceived, developed and carried out by the workers themselves, as generic beings, shape and develop their own survival strategies. The Social Economy isn't itself a finality has no life of its own, it's the fruit of the labor of the man that is the objective and if it protrudes as a social being.

The Social Economy isn't new way. It was born in the 19th century in the early days of the Industrial Revolution in

${ }^{1}$ The centrality of work, while speech, emerges in modernity, while the ontology of the work also while speech, is very old. Dating back to the approaches of St Augustine (Hypo (354-430) fourteen centuries before Marx write the economic andphilosophical manuscripts (See Salamito-2005). 
the name of what we now know as cooperativism. At that moment in that Europe went through profound changes originated with the "revolution of the machines ", large plots of workers were excluded from the production process. The way to deal with the situation of marginalization of productive population quotas was the cooperative model. It was thus that the cooperatives have emerged, "in an attempt, in time naive, to replace the capitalist enterprise unequal and exploitative by industrial companies modern, democratically contract catering for their workers" (SINGER, s/d. p. 84). ${ }^{2}$

The origin of cooperative system comes from very far away. It was born with the British workers in mills of cereals from the 18th century (1760). Then came the cooperative of consumption of weavers of Fenwick in 1769 and in 1795 created the Oldham Cooperative Supply Company. In 1823 there were already 160 associations in France that subsequently gave rise to workers' cooperative production.

This first attempt of associativism isn't prospered, and it is therefore considered the milestone of cooperativism modern society of Probos Pioneer of Rochdale, created in 1844, in Manchester, England with Robert Owen. For Singer (2000, p. 13) , "the economy of solidarity could not precede the industrial capitalism, but accompanies it as a shadow in all its evolution, because it is a creation in a continuous process of workers in struggle against capitalism".

\section{The Brazilian Way Cooperative}

There is in Brazil a tradition of cooperative consumption since 1887, initiated in Sao Paulo and Minas Gerais, after reaching the Rio de Janeiro and Rio Grande do Sul in credit cooperatives, which walked slowly until 1930. From period, the great depression world stimulated the emergence of cooperatives, especially in the South of the country. In 1932, the Vargas Government regulated the operation of cooperatives through Decree no. 22. 239, A measure that has boosted strongly the cooperativism Brazilian. The material incentives and tax directed to cooperatives from 1945 and the creation of the National Bank of Credit Cooperative (BNCC), but in 1951, was extinguished in Collor's Presidency, constituted it a institutional mechanisms important to the development of cooperatives in the brazilian nation.

It's necessary to consider that in Economy post-Second World War was created the Welfare State in capitalist countries advanced Europeans, such as France, a combination ford's Keynesianism. The social support to workers advocated by Keynesian thesis as the full employment, social benefits, and, in certain purchasing power by allowing them to get rid of the inventory of goods, associated with the guarantee of social rights such as health, social security and social assistance of responsibility public state, contributed to make associations to the condition of State apparatus. According to Barbosa (2007, p.91),

In general, the cooperatives also have succumbed to a greater formalization, adapting it to the requirements of the competitiveness of the market economy with the modernization of the productive forces, the expansion of organizational structures and the bureaucratization of participatory practices.

Beginning in the 1970s when the economy of the European countries have begun to show signs of abating, going into a decline and deceleration, whose apex of crisis led the GT7 (composed of the United States, Canada, Germany, England, France, Italy and Japan) to convene the fateful meeting in 1989 that became known as the Consensus of Washington, ${ }^{3}$ the theme of Social Economy is put back on the agenda of new databases. In Latin American countries such as Cuba, Chile, Puerto Rico among others, this modality of work receives the name of social economy, little known in Brazil.

As regards the concept of Social Economy it must be acknowledged, ready, that its substrate heuristic is based on democracy and solidarity between workers who, in a collective way and with strong appeal of meeting and cooperation, mobilize their energies and political strength to create and administer ventures economic-social. It is practices not only economic, but also social, political and cultural signification of entry modes of workers in social totality. Santos (2002, p. 19) points out that there are here.

The virtuous passing between technical knowledge and popular knowledge of which were generating new spaces of democratic deliberation and cultural development ... in which the productive activities has dimensions beyond the economic perspective, since (the workers) express a local culture ... and a way of living and being in the world.

\footnotetext{
2 The birthplace of thought western cooperative stand out the utopian socialists as Roberto Owen (1771-1837), William King (17861865), Charles Fourier (1772-1835), Philippe Buchezi (1796-1865) and Louis Blanc (1812-1882) who formulate the main ideas and principles that move the cooperativism modern.

${ }^{3}$ Roughly, this meeting was held in the city of Washington, in the United States, recognized the crisis of capital and put in motion the process of productive restructuring on the basis of a neo-liberal perspective to minimize the actions of the State, which should privatize it's state and its services, and downsizing of the business machine with excessive reduction in jobs and global requirements within the scope of competition in the market.
} 
The being and living way in the world to recalls the principle of freedom, of free subjects, able to transcend itself in a process of otherness. There is a prospect of the construct of becoming human with the other, by rehabilitating the collective of doing together, weave together a resignification of class and of his becoming like a Thompson way. The human aspect of organizational management cannot be supplanted by methodological guidelines and technical arid. The affectivity in social relations is essential for the maintenance of unity and cooperation. The sociability of the popular parties and leisure, as we will see along since study, is the fundamental element that weaves the brotherhood and fraternity.

The size legal-institutional assumed by Social Economy in Brazil, this new format that is spreading in the country from 1990, as we said earlier, is based on cooperativism and associations managed by these groups themselves. Seems us to point to the structural replacement of formal work, doing the upgrading of informal work and repositioning it in the public level.

Another side of the concept of Social Economy is political dimension its. A first political element displayed is the appearance of this popular work modality, whose prerogative is the social emancipation of socialist complexion. Brings the criticism on the solidarity that in times past did not prevailed in the country, because the cooperativism once facing the agribusiness, not poured roots in people's collective. The emphasis on the autonomy of workers seems to be "an inheritance same social struggles for democratization of the country, particularly the culture of resignification of practices of appointed new social movements" (BARBOSA, 2007, p.89).

Another political Element that composes the concept of Social Economy affects subject inducers of these practices. As we said earlier the Brazilian universities were the first subject inductors along with the Unique Center of Workers, then it came the social movements, the church, especially the Diocesan Caritas, political parties of the left, especially the Workers Party and civil organizations of human rights. There seems to be a certain displacement of stringent action in defense of jobs and the quality of labor relations, together with public authorities and business to put into developing pragmatic actions of creation of survival strategies. In the design of Barbosa $(2007,90)$, seeks to give.

Emphasis on positivity of experiences before the human problems of large scale in this end of the century, such as, for example, the destructive effect of the logic of capitalist accumulation on the environment and the workers, both in terms of quality of life such as unemployment and poverty.

As you can see the Social Economy is based on a set of ideas ethical-philosophical and conceptual that evokes the democracy, solidarity and the assuage aspect of work. Come join this set of ideas the militancy and the political role of workers organized in solidarity ventures, with the contribution of inducing agents that make the mediation of these methodological practices.

It is not, moreover, shares simple and easy to conduct. The Social Economy does not develop as in the capitalist system that dictates the enterprise standards and orders that are adhered to by all. In the capitalist system the workers are controlled and displaced in their functions in a simple touch of the box. The Social Economy workers are self managers, are the subject of its own decisions and this requires respect their cultures of democratic organization and popular participation.

The form of organization of work contained in the cooperative is the most representative of the solidarity economy. In all the cooperatives that have more opportunities to show your entire economic potential is the production cooperative. In this type of cooperative takes into account the greater involvement of the worker, which makes the profit, dividend, as its production. If the worker produce little he receives little, if produce very receive too, and if not producing anything in the month also does not receive anything.

The division of the profits of the cooperative is carried out fairly and not equalitarian. The fair means that must be passed on to the employee by the value that is right for him, because, according to their production, and not the equal division between all involving those who worked and those who did not work in the same proportion. The second important aspect of the cooperative is the transformation of the value added (profit surplus) in excess (SINGER, 1998). At the end of the year, when it is done the general balance sheet, the remainder is divided equally between the partners. This is the type of cooperative that we are analyzing in this study in the context of APRODUCIDA (Picture 1), which is a cooperative of agricultural production. 


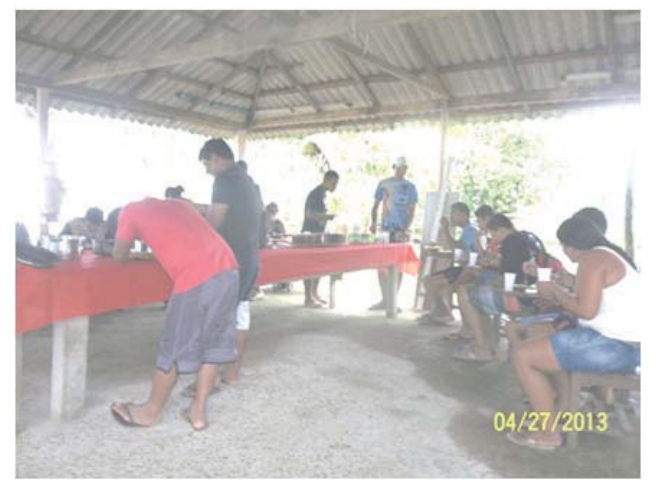

Picture 1 - Meeting in Aproducida Rural Coopertative. Localized in Rural Village Nossa Senhora Aparecida. CoariAmazon State (Brazil)2013.

There are other types of cooperatives as the service that are those outsourced enterprises through subcontracting, and there are other considered cooperfraud, because these are initiatives that use the prerogatives of cooperativism to not pay labor rights, tax due to the State and other legal facilities. This type is not supported in the set of cooperatives within the economy of solidarity.

It is, in this respect, that not all forms of informal work are considered solidarity economy. It is those economic initiatives that "do not apply the principles of collective ownership of the means of production and of self-management: the itinerant worker standalone and the small group of production controlled by the owner of the capital available, even the smallest, are some examples" (FRANÇA et al, 2008, P.17).

The solidarity and collectivist aspect, present in the concept of solidarity economy, is of singular greatness in the process of human development. Unlike the relations of exploitation governing capitalist societies and that lead workers to immanence and reification, the Social Economy raises the self-esteem of workers recreate and reinvent the process of work. The democratic character of the Social Economy is essential to the functionality of the enterprises. The realization meetings, the existence of ethics committees, the signatures contracts and the creation of financial funds to ensure the practicality of actions should not be neglected. This organicity is ensures the success of the project and gives the assurance that all revenue will be reverted to the cooperative itself and for the cooperative's members.

\section{The Case of Rural Village Nossa Senhora Aparecida - Coari, Amazonas (Brazil)}

Our survey was conducted in rural Village called Nossa Senhora Aparecida, in the District of Coari, highlights the work of cooperative Community Association of Rural Producers of Community Nossa Senhora Aparecida, which is called for the popular name of Aproducida. In an interview with one of the leaders of the community we were told that "the cooperative was founded in 1999 because we realized that we were past pra behind with the sale of our products to a Japanese. We sold to him at a price well below and he resold with goodwill" (Lucivânia, 35 years, interview/ 2013). According to Culti (2002, p. 3),

Is the people excluded that initiatives have been taken with expectations to meet their needs and open new paths in life, through the use of their own strengths and resources, by associating it to other and organizing themselves in groups, associations and cooperatives. They are, therefore, organizations or collective community in defense of individuals as citizens, residents, consumers and workers.

The formation of the community Nossa Senhora Aparecida dates back to the late 1970s, when a group of people who have ties of kinship was moved from the rural area of the municipality of Manacapuru, in the State of Amazonas, in the rural area of the municipality of Coari where it was built new relationships with the place, founding the new community. As Damian Mota (58 years), "the reason for the offset of these families occurred because of survival. The place where we were living was becoming scarce, difficult, then went out for live better here" (interview/ 2013). As Culti (2002,p.4 ), "the experience of economic organizations popular that emerge from excluded or more poor constitute a real initiative in development. Are forms economic solidarity in which the work takes center position".

One of the elements potentiated in contemporary time and that appears in the bulge of productive restructuring, it is the discourse around the centrality of work. The centrality of work became an arguable issue that goes from factions of 
center left until the left radical. This question is grounded in moderate left group Marxist theory of the Frankfurt School, as is the case of Habermas which it considers to be the announcement, or better, the communicative action to centrality. The world of life is that should control the world system, says Habermas (1987). It is substantial changes that tend to remodel the meanings of work while activity of human construct.

When we questioned the subjects in this research the reason for the displacement of people from their places of origin to the community Nossa Senhora Aparecida, we found that it is the job and the best marketing of agricultural products (picture 2), which motivated them to seek another territorial area. Graciete Mota (35 years) shows that "for us and our family work is everything, where we we were living the land was not good and the price of production was very low" (interview/ 2013).

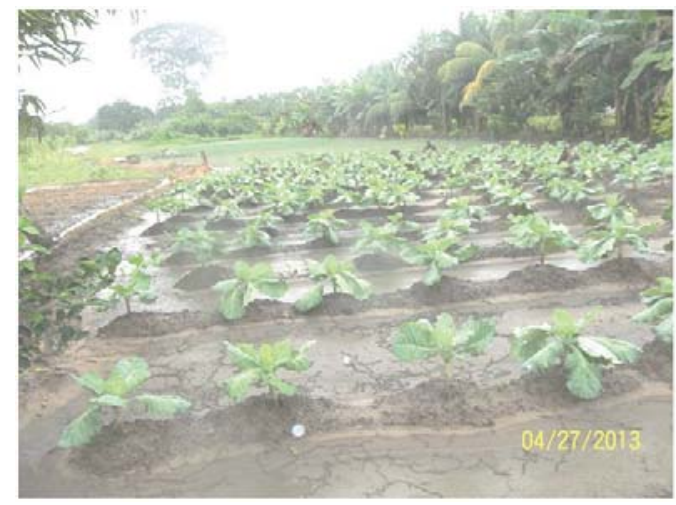

Picture 2 - Rural Village Nossa Senhora Aparecida. Coari-Amazon State (Brazil)2013.

See, there is this speaks a strong appeal to the centrality of the work. The job is everything, that is, it is life itself, the large vector under which workers produce the means of their material existence. The immaterial life is also inside with the work, if we consider that in the case of the Amazon, the traditional peoples establish a strong bond with the forest, land and rivers.

Asked about the reasons that drove the creation of the cooperative in the community Nossa Senhora Aparecida, the Aproducida's Executive Officer revealed that "it's for the residents have a financial life better with a participative management. It's also a way of organizing the community itself" (Damian Mota, interview/ 2013). Another subject of the research says that solved organize themselves into a cooperative "for our community is strong, if strengthen collectively in order to claim more" (Lucio Barbosa, 61 years, interview/ 2013).

Organize the community through cooperativism implies adoption of principles, objectives, methods and methodology, referring to the construction of a new organizational culture. According Garay (1997, p. 48).

An organizational culture can be defined as a set of understandings, interpretations or perspectives shared by individuals in the sphere of a company or cooperative, representing a complex network of principles, values, beliefs and assumptions.

In the case of cooperatives the principles of democracy and solidarity are central in the organizational ventures level. In cooperativism popular workers are directly involved in the management of the business. The rules of operation and the referrals are taken collectively constructed in appropriate forum that is the meeting with the members. Within this democratic process the principle of solidarity and the collectivist spirit of unity and cooperation are the founders, pillars that support this organizational culture established through the democracy. Singer (2002, p. 9), however, pay attention to the fact that "the solidarity in the Social Economy can only be carried out if it's organized also by that associate themselves to produce, to sell, to consume or to save. The key to this proposal is the association between equal instead of contract between unequal".

The Social Economy affects the life of the community and with the organizational structure of families. When we questioned about the interference of the cooperative community, Lucivânea Barbosa (35 years) said that "changed the way of life. All are earning money" (interview/ 2013). Another interview said: "gave a turning point in our lives, we have a financial life better with villas more appropriate. Everyone has made improvements in their homes, have their engines, all have canoes" (Francinete Mota, interview/ 2013). 


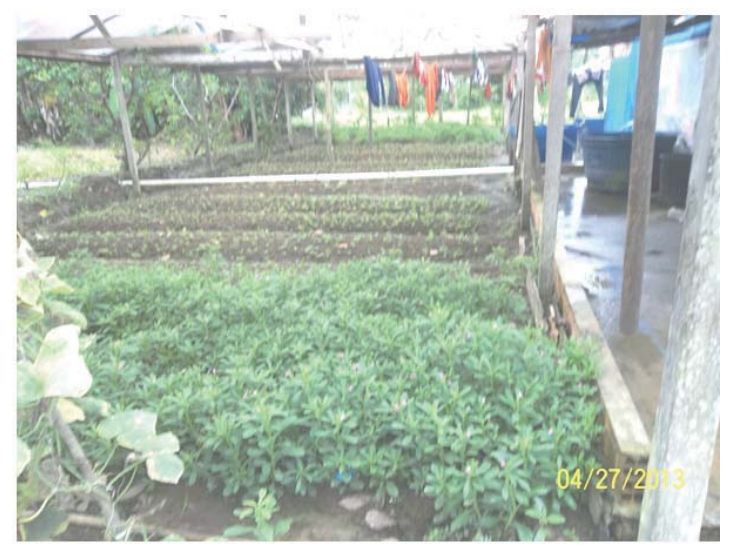

Picture 3 - Vegetables produced for the rural schools.Rural Village Nossa Senhora Aparecida. Coari-Amazon State (Brazil)2013.

Observe that the economy of solidarity but it is a possible alternative and viable to the process of social exclusion, it has an impact on the situation of poverty to the extent that it improves the quality of life of workers. According Singer (2000, p13).

The supportive of production and distribution seems at first sight a hybrid between capitalism and small production of goods. But, in reality, it is a synthesis that surpasses both. The typical unit of Social Economy is the production cooperative, whose organizational principles are: possession of collective means of production by the people who use them to produce; democratic management of company ... ; allocation of net revenues between the members by criteria approved after discussions and negotiations between all; allocation of annual surplus (called leftovers) also by criteria settled between all members. The basic dimension of capital of each cooperating isn't has remunerated, additional sums loaned to cooperative provide the lowest rate of interest on the market.

If the cooperative members watching the canons of organization of joint venture everyone wins. The differential of this type of work organization is the great value assigned to democracy and equality within the enterprises. The self is the soul of business; everyone must contribute to its success, a repudiation of submissive. No cooperated must leave loophole, vacuum, to which the leader if you think "owner" of the project. No worker cooperative is an employee of the cooperative, in truth they are the owners, is the cooperative that receives the dimension or rate of each employee to make the administrative maintenance of the enterprise, and not the contrary. This is the reality detected in Community Association of Rural Producers of Community Nossa Senhora Aparecida. As Francinete Mota,

The members deliver the production for the President of the Association, he gives the production (benefits), $20 \%$ is for the enterprise and the rest is divided in proportion to the members in accordance with their production. Who does not produce, you don't win (interview/ 2013).

\section{Concluding Remarks}

This is the great challenge to cooperativism: the equal division of profits. The fair is not equal, it is what is fair. The proportionality in the division of profits is now confined to the quantity of production. The agricultural products produced by members of APRODUCIDA: vegetables, grains and fruit, as we shall see later, are to the Municipal Secretary of Education of the District of Coari, to compose the school meals for students. Then, there is a need for effort of all members to be able to give account of this responsibility. Singer $(1998, p .38)$ calls attention to the fact that "workers in production cooperatives do not obey anyone, hasn't boss and, on the other hand, cannot make body mole, as is often the case with people who have those who pay his salary at the end of the month".

The Social Economy doesn't operate with the unbridled profit own the molds of accumulation, in fact, this type of rural associations of family based can't compete with companies in the agribusiness sector, it would be naive to think in this scale. The Social Economy creates conditions of profits in the context of survival appear to be sustainable in the eyes of the market. The principle of self-determination is the great challenge of creating direct forms of popular power in several levels: associations, cooperatives, local productive arrangement, self-administrating companies etc. This is a 
social revolution in potential, whose implementation or is not a future possibility.

\section{References}

Culti, Maria Nezilda. O cooperativismo popular no Brasil: importância e representatividade. Trabalho apresentado no Terceiro Congresso Europeu de Latinoamericanistas, realizado em Amsterdã - Holanda, 2002 (mimeo).

Garay, Ângela. Cultura organizacional. In: CATTANI, Antônio David (org). Trabalho e tecnologia: dicionário crítico. Petrópolis, RJ: Vozes; Porto Alegre: Editora da UFRS, 1997.

Habermas, Jungen. Teoria de la acción comunicativa. Madrid: Taurus, 1987.

Marx, Karl. Manuscritos econômico-filosóficos. Traduzido por Jesus Ranieri. São Paulo: Boitempo, 2004.

Ranieri, Jesus. Apresentação dos Manuscritos Econômico-filosóficos de Karl Marx. In: Marx, Karl. Manuscritos econômico-filosóficos. Traduzido por Jesus Ranieri. São Paulo: Boitempo, 2004.

Salamito, Jean-Marie. Trabalho e Trabalhadores na obra de Santo Agostinho. In: MERCURE, Jan Spurk (org). O trabalho na história do pensamento ocidental. Traduzido por Patrícia Chittoni Ramos Reuillard e Sônia Guimarães Taborda. Petrópolis, RJ: Vozes, 2005.

Singer, Paul. Economia solidária: um modo de produção e distribuição. In: SINGER, Paul e Souza, André Ricardo de (org). A economia solidária no Brasil: a autogestão como resposta ao desemprego. São Paulo: Contexto, 2000b.

Singer, Paul. Introdução à economia solidária. São Paulo: Fundação Perseu Abramo, 2002. 